〔水質污濁研究 第 4 巻 第 5 号 $271-276$ 1981]

〈講座〉

\title{
ウイルスと水污染 (VI)
}

\section{Viruses and Water Pollution}

丘依 枢 ${ }^{*}$

Yishu CHIU

\section{水系ウイルスの伝播とコントロール}

\section{1. 水系ウイルスの伝播}

下水や下水污泥中のウイルスは, 処理の過程を経て減 少するがその一部はなお残存して感染源となる。ウイル ス病の感染源こしてはこの他に人間が排泄するし尿や生 活の営みによって生じたゴミなどの廃棄物があげられる。 いろいろな経路を通じて, これらの感染源に含まれてい るウイルスは，再び人間の体内に侵入し病気をひき起こ す可能性を持っている。環境に排出されたウイルスは， 水や空気の流れによって移動したり, ベクタ一（vector） と称される節足動物や鳥類によって遙か遠くまで伝播す る。ベクターによる伝播としては, ベクターの体にウイ ルスが付着し, その移動によって運ばれるのが最も簡単 な方式である。

しかし, ウイルスの多くは水によって伝播することが 可能であり，以上のようなさまざまな伝播経路のうち， 水系によるものは特に重要である。水に何らかの関わり を持つウイルスの主な伝播様式を図1に示す。図からわ
かるように, 下水とその処理によって発生した污泥, 家 庭のし尿やゴミ,これらはいずれも病原体を保持しなが ら, さまざまな経路を通じて, 水源, 農作物や魚介類, さらに空気にまで污染を及ぼす。ウイルスに污染されて いる水を飲用したり, 污染をうけた農作物や魚介類を食 用にすると, ウイルスは適当な条件の下で人間に感染す る。

糞便, 下水, ゴミな゙, 各種感染源のうち最も注意を 要するものは䔬便であ万う。いうまでもなく䔬便にはウ イルスがひんぱんに含まれている。特に熱帯地域では, 子供の $30 \sim 50 \%$ までが, 年中, 1 種ないし多種のウイ ルスを含む粪便を排泄し, 子供の糞便の半数以上が何ら かのウイルスを含有している。粪便とともに排出される ウイルス, その殆んどが腸内ウイルスといっても差しつ かえないが, 暖かい地域の子供の $1 \sim 2$ 割は, 腸内ウイ ルスの1種であるエコーウイルスを粪便に排出する。

ところで, ウイルスを含む粪便を排泄するのは, ウイ ルスの腸管感染症状を呈している人だけにとどまらない。 病気の種類によって異なるが, 1 人の発病者につきその

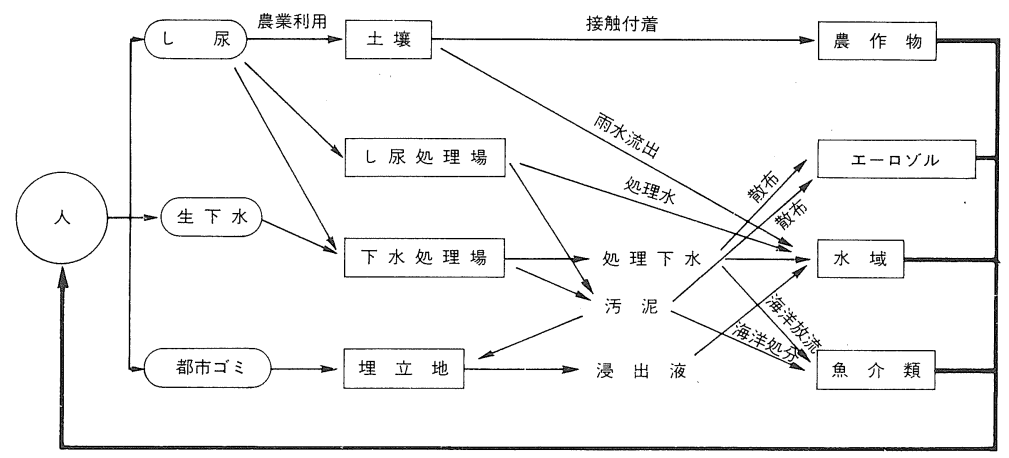

図1.水系ウイルスの主な伝播経路

* 烌)日本水道コンサルタント $\mathbf{7} 160$ 東京都新宿区大久保 2-2-6 Nihon Suido Consultants Co., Ltd. (2-2-6 Okubo, Shinjuku-ku, Tokyo, Japan 160) 
背後では 100 人， 1000 人もの一見して健康で症状を呈 していない不顕性感染者（inapparent carriers）が, 同様にウイルスを含んだ賴便を排出する。なお患者にお いても, 症状が消えた後もしばらくの間は,ひき続き䔬 便にウイルスを排出する。このような腸管感染のほか, 呼吸器で伝染するウイルスも糞便に排出されることがあ る。

ウイルスは粪便に残存して数ケ月もの長い間, 活性を 保ち続けることもあるが, 普通はいろいろな媒体によっ てたちまち四方に伝播する。下水道が完備されていない 地域や浄化槽が設備されていないところでは，便所に排 泄されたし尿は, 汲み取られ, 処理されないまま処分さ れたり利用される。汲み取ったし尿を直接農地に散布し, 肥料として利用するケースは, 開発途上国に多く見られ るが,この場合, 農作物の病原体污染は避けられないも のとなる。また, し尿が栄養源として魚の養殖池に添加 されることもあるがそのような場合はし尿に含まれてい るウイルスは魚に感染することになる。農村やキャンプ 場では, 素掘りの便所や単なるピット（pit latrine） にし尿を排泄するケースも少なくなく，し尿が土壤に浸 透して, ウイルスの地下水污染やさらには井戸水污染を ひき起こす。

病原体を含むという観点から，し尿に次いで重要なの は未処理の家庭下水であろう。下水道の整備されていな いところでは, 家庭の雑排水はし尿とは別に側溝に流さ 机る。これは, 地下に浸透するか, あるいはそのまま流 出して環境水域を污染する。し尿を伴わない雑排水とは いえ, いろいろな洗浄排水を含むため, 病原体を含有す ることに変わりはない。

下水道の整備されている地域では, 家庭下水は収集さ れ,さらに下水処理場で処理されて放流される。しかし, 処理された下水でも絶えずある濃度のウイルスを含有し ている。米国テキサス州, Houstonの下水処理場での調 查では, 毎分 $(0.3 \sim 6) \times 10^{6} \mathrm{PFU}$ のウイルスが処 理下水に含まれて排出され，これは 1 日あたり（0.4〜 $9) \times 10^{9}$ PFUのウイルス量に相当する。 ${ }^{2)}$

糞便や下水ほど深刻ではないが, 都市ゴミもまた感染 源である。都市ゴミには, 㕑芥や雑芥の他使用済みの紙 オシメも含まれており, ウイルスなどの病原体を伝播す る可能性がある。以前は, 使い捨ての先端を切ってきた 開発国にしか見られなかったこのような現象も，現在で は他の国々にも現われるようになってきた。紙オシメが 広く普及している米国での, 都市ゴミに糞便で污れた才 シメがどの程度含まれているかについての調査結果, そ の割合は $0.2 \%$ か $2.5 \%$ 範囲で変動しているとの報 告があった。このようなオシメの $11 \%$ に ポリオ 3 と エコー2ウイルスが検出された。
病院から出る特殊なゴミは, 大体, 焼却して安全化を 計っているが, 都市ゴミもこのように焼却すれば病原体 を伝播する恐れはなくなる。しかし大気污染が問題であ り，他の処分方法として埋立や堆肥化が行われている。 埋立処分の場合, 埋立地に雨水が浸透して病原体が浸出 液に伴なって付近の水域を污染する。

以上のように, いろいろな感染源からウイルスが伝播 し, その結果, 私達の日常生活に欠くことのできない飲 料水や食物, あるいは食器などを污染する。飲料水の污 染は, 污染された水が, 直接飲用されるために特に厳重 な注意が必要である。また, 污染された水で食器を洗う と, ウイルスは食器を媒介として人間に感染する。水道 施設のない地域では, 家庭用井戸などの使用によって感 染をうけるというケースが少なくない。給配水系統の完 備されている所でも, 浄水場での消毒の不完全や給配水 管のき裂で污染を受ける。浄水場で十分な消毒が行われ たとしても, 給配水系統の末端で水圧が低下してサクシ ョンとなると, 切れ目から活れた水を吸引して水道水を 污染させてしまう場合がある。

流行性肝炎は水を伝播して感染することが多いが, 米 国マサチュ一セッツ州, Worcester で1969 1970年に発 生した流行性肝炎の疫学的調査の結果, 上下水道管が老 朽化しているうえ水圧が低いといった地域では, そうで ない対照地域にくらべて疫病の発生件数が多かった。 ${ }^{4)}$ 別の研究によれば, 米国で, 単に配水管への污水浸入に よる流行性肝炎の発生件数は, $1946 \sim 1974$ 年の間に 6 件もあり, 総患者数は 177 人にも達した。また,すべて がウイルスによるとはいえないが，同期間の同様な原因 による消化器疾患の発生は 9 件で, 総患者数は 1312 人 であった。

水道による疫病の特徵は発生区域が給水区域に一致す ることである。給配水系統の末端で病原体の污染をうけ た場合は, その疫病は局部的なものにとどまるが, 水源 や給配水系統の上流で污染をうけると, たちまちにして 大流行の疫病に見まわれることとなろう。

ウイルスは飲料水のほか, 農作物を通じても人間に感 染する。し尿, 下水や下水污泥を農地に利用すると, 病 原体は土壤を污染し, さらに植物の根と接触して適当な 環境の下で組織内部に侵入する。その他ウイルスは植物 の茥や葉に接した場合，そこから侵入することもできる。 動物の細胞内でしか増殖しない動物ウイルスでも, 種類 によっては植物の表面ばかりでなく内部にまで侵入する ことも可能である。

処理下水の灌溉利用についてのある調査によると, 灌 溉をうけた野菜の 25 のサンプルのうち，2つにエンテロ ウイルスが検出された。 ${ }^{6 ）}$ また, キャベッ,こしょう, トマト，それぞれに人為的にェンテロウイルスを感染さ 
せた調査では, ウイルスは各々の野菜に 4 日， 12 日， 18 日間という長い間生存していた。”）このようなウイルス に感染している野菜を生で食用すれば人間もウイルスに 感染し疾病をひき起こすことになる。

生活の営みによって生じた排水や廃棄物は, 前述のよ うな農地緑地利用や陸地処分の他に, 海洋処分も行な われている。海洋への下水放流や污泥投棄は陸地の感染 源を単に海域へと移転したにすぎない。下水や污泥の放 流点付近で漁獲されたカキなどの魚介類にはウイルスの 污染が見られる。魚介類は数時間でウイルスを濃縮蓄積 することができるので, 放流点から遠ざかった水域でウ イルスが希釈されたとしても, 濃縮作用によって魚介類 の体内により高い濃度で存在する。

米国の Texas Gulf 海岸のカキ養殖池でエンテロウイ ルス污染のモ二ターが 10 ケ月にわたって行なわれた。 ${ }^{8)}$ カキのサンプル数 40 のうち，14にウイルスの感染があ り，その濃度はカキの肉 $100 \mathrm{~g}$ あたり $6 \sim 224 \mathrm{PFU}$ で あった。このときの水のウイルス濃度は試料水 100 ガ口

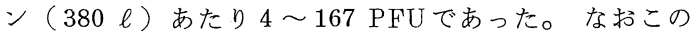
他の 5 件の調査で水域にウイルスの検出がなかったにも 拘わらず，カキにウイルスが検出されていた。魚介類に 検出されているェンテロウイルスにェコーやポリオがあ る。しかしェンテロウイルスと同じょうに腸管系ウイル スに属する流行性肝炎ウイルスのほうが魚介類に関連あ る病原体として世間を騒がせている。1955 年スウエデン で流行性肝炎の疫病が発生し，630人の患者を出した。 $\left.{ }^{9}\right)$ 疫病の原因はウイルス感染のカキを食用したためである ことが分かった。魚介類の媒介によっても流行性肝炎が 発生するということがここで始めて裏付けられたことに なろう。米国では 1961 年メキシコ湾沿岸 (Gulf Coast) で 84 人 $^{10)}$ ニュージャージー州および東北東部の各州で合 計 485 人，また 1964 年ニュージャージー州南部およびペン シルバニア州の Philadelphia で 193 人, さらにコネテ ィカット州で 123 人の患者が発生した。 ${ }^{11)}$ 沿海州では魚 介類の摂取量が多いため, 流行性肝炎も多く発生したの ではないかと見られている。

他の病原体と同じように, ウイルスは飲料水や食物の 摂取によって体内に侵入感染するほか, 鼻から吸い込む ことによっても感染する。下水処理場の曝気槽から, そ して下水散布のスプリンクラーからウイルスなどの病原 体が泡沫に伴なって飛散している。スプリンクラーの風 下 $40 m$ で採取した空気のサンプル 12 のうち，4つにエ コー7 型のウイルスが検出されていた。 ${ }^{12)}$ 下水や污泥の 処理度合, 気象条件, ウイルスを含んだェーロゾルの走 行距離などによって伝播感染の確率は異なるが, 一般に エーロゾルは長く空気中に浮遊し, また数 $k m$ も遠方に運 ばれることができるので, その確率は非常に高いといえ
る。下水や污泥の処理程度が低いほど,また近くに人口 が密集しているほど, エーロゾルによるウイルス感染の リスクが高い。

イスラェルでキブッと呼ばれている農村の生活共同体 では, 水資源不足のために下水の灌溉利用が盛んに行な われている。下水灌溉の農作物の生食は禁止されており， 食物による感染は問題がなかったが、エーロゾルによる 空気感染のほうは深刻であった。ある調査によると下水 灌浤利用の区域は非利用の区域にくらべて流行性肝炎が $2 \sim 4$ 倍も高い率で発生している。またカゼで医師にか かった人は下水利用区域のほうが 2 倍と高かった。 ${ }^{13 ）}$ 一ロにカゼといってもいろいろなウイルスが関与して掠 り，そのうちアデノウイルスは腸内ウイルスの 1 種とし て下水にもよく見出されるものである。

\section{2. 疫学的所見}

水系ウイルスのうち, 疫学的に重要なのは何んといっ ても流行性肝炎やポリオ（急性灰白髄炎）の原因となる ウイルスである。現在ではワクチンの使用にようてポリ オの疫病は以前ほど顕著ではなくなったが, 開発途上国 や未開発国では現在なお散発的に流行している。なお流 行性胝炎に至っては病原体の掊養法すら確立されていな い現状に掞いて，水質管理や環境衛生が強化されない限 り当分の間はこれまで通りに発生するだろう。上下水道 や便所が完備されておらず，環境衛生の悪い地域では流 行性肝炎もポリ才も同様に流行しており,とくにポリ才 の場合では夏から秋にかけて幼児の間に多発する。

流行性肝炎は長い間, 世界的規模で発生している。粪 便污染の飲食物によるほか，たびたび水系を通じて大規 模に流行する。水系による流行性肝炎の大規模発生は大 部分が公共水道の下水污染に起因しており，そのうちで も良くひき合いに出されるのがインドの New Dehliで

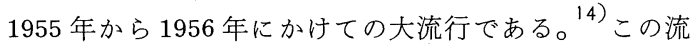
行で数万人もの患者が発生し，不顕性感染者を入れると 数百万人にも達するだろう。公共給水という文明がかえ ってこのような大規模な結果をもたらしたということは， いかにも皮肉である。都市給水の水源であるJamuna 川 の河川水が逆流したため, 放流下水が上流側の取水口に 流れ込み, その結果, 水道の原水に下水が $50 \%$ も混入 した。浄水施設には故障がなく，塩素消毒もこれまで通 りに機能していたが, 病原体のほかに有機物も高い濃度 で含まれていたため。ほとんど効果がなかった。その原 因を察知し，塩素濃度を高めて消毒の強化を計ったが， チフスなどのバクテリア性の病気は防げたものの, ウイ ルス性である流行性肝炎のまん延をコントロールするほ どには至らなかったのである。

米国では近年, 年間数万人もの流行性肝炎患者が発生 
しており，そのうちの約 $1 \%$ は明らかに飲料水が原因で あるとされている。1961〜1970 年の.10 年間の発生件

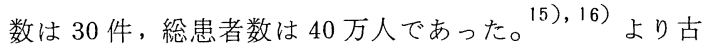
い記録では 1945 年夏ペンシルバニア州, Philadelphia 近郊のキャンプ場で井戸水の粪便污染で, 参加者 573 人 のうち, 半数以上の 350 人が流行性肝炎に感染した。 ${ }^{17)}$ また 1961 年, 冬から春にかけて北東部の州で流行が起 き, 数百人の患者を出し, その半数がはまぐりを生食し たことに原因があると見られた。18)

流行性肝炎の集団的発生は日本においてもたびたび見 られた。最近の 1 例では 1977 年 6 月, 佐賀県の小学校 で井戸水の污染が原因で約 490 人が感染した。

つぎはポリオについて見てみよう。腸管感染のポリオ は流行性肝炎以上に恐しいウイルス性の病気で, 水系を 通じても流行する。世界的規模でひんぱんに発生してき たこの種の疾病も近年では開発途上国にしか多く現われ ないようになってきた。開発途上国を主とするアフリカ アジアおよびラテン・アメリカの $1977 \sim 1978$ 年の 1 年 間のポリオ感染者数は 8000 万にも達し, そのうちの 1 万 ないし 2 万は命まで失った。 ${ }^{19)}$ 運よく一命をとり止める ことができたとしても, 腸管感染だけで斉まないポりオ ウイルスがさらに運動神経の細胞に感染するとマヒとい う身体障害の後遺症を残すことになる。

日本もつい 20 年前までポリオの流行をたびたび経験し てきたが，その後はだんだんと姿を消した。その経年的 変化を朓めてみると 1960 年は大流行で全国で 5600 人の 患者を出したが，ワクチンの使用により 1962 年は 289 人に激減した。なお 1970 年ではさらに 10 数人に減少, そして 1976 年からはほとんど消えてしまった。 ${ }^{20)}$

米国でのポリオの流行については1907年が記録の最初 であろう。12 年後の 1929 年にそれが水系によって伝染 するということが推定された。1940年, 下水污染の水泳 場を介して地域的に流行が起きた。 ${ }^{21)}$ その後の主な流行 例を挙げると 1952 年ネブラスカ州 Huskerville で都市給 水系統の欠陥によって污水が水道水を污染した結果 45 人 の患者を出し，そのうち 17 人がマヒになった。 ${ }^{22)}$ 患者の 多くは污染個所に近い住民であり，遠く離れるにしたが って感染者数は減少した。この流行は塩素処理の強化で おさめることができた。また 1959 年アイオワ州Des Moines 137 人の患者を出し, そのうち $52 \%$ がマヒを伴 った。 ${ }^{23)}$ その間, 家庭下水や糞便を数週間にわたって調 査した結果，ポリオウイルスが検出された割合は 37.5 75. $0 \%$ であった。

米国の隣の国, カナダでは 1953 年,アルバータ州の Edmond で 75 人のポリ才患者を出し, その後の疫学 的 調覔で都市に給水している河川の水源が感染源であるこ とが分かった。取水口の上流, $3.6 \mathrm{~km}$ のころに位置す
る下水処理場の塩素消毒装置が故障したため,このよう な事態を招いたのである。 ${ }^{24)}$

流行性肝炎やポリオほど深刻ではないが, プール熱 (咽頭結膜熱) として広く知られている病気も水系によ って伝染するウイルス性のものである。病原体であるア デノウイルス（主に 3 型）は毎年のように，とくに子供 のプールを介して伝染している。日本での主な流行例を 見ると, 1959 年横浜市保土ケ谷区内の子供プールで 700 名余りの患者が発生した。同じ区内の子供の間に 1970 年, 再びプール熱が集団的に発生し, 今度は 800 人以上もの患者が出た。 ${ }^{25)}$ プール熱の他に流行性角結膜 炎もアデノウイルス（8型）によってプールを介し, 発 生する病気である。アデノウイルスの他, プールで検出 されているウイルスにエコー（6型， 7型）やコクサッ キー（B 6 型）がある。

伝染性下痢症とか非細菌伝染性胃腸炎 (infectious nonbacterial gasenteritis) とかいうように呼ばれて いる病気もウイルスによるものと推定されており,これ も䔬便の污染によってひんぱんに水系を通じて特発的に 発生している。流行性肝炎やポリオ，またはプール熱の ように注目されていないが,この種の胃腸炎は水系の伝 染病として最もひんぱんに発生しているのである。

\section{3 . 水系ウイルスのコントロール}

水系ウイルスに起因する感染症を予防するためにはい うまでもなく環境衛生の向上, とりわけ便所の改善や上 下水道の普及, さらに水質管理の強化を最も基本的な対 策として考えなければならない。下水道が整備されてい ない区域では浄化槽を設置して水洗便所にしたり，素掘 りの便所よりも水密性のものにするなどして最も重大な 感染源である糞便が生活環境を污染しないようにするこ とが肝要である。便所の設備が行き届いていないところ では, 子供はとかく側溝や水路沿いで排便しがちであり, それが雨水に流され。水域を洉染する。いろいろな調査 によると便所の設備の改善で, いままで多く発生してい た水系伝染病が地域的に減少してきている。これは飲料 水の水源ともなる水域環境がそれだけ病原体や病原菌を 含んだ䆏便の污染から免れてきたことにほかならない。

安全な飲料水の供給もまたこれ以上に疫病の多発を防 止してきた。しかし，水道の設備に欠陥があったり，消 毒が不完全になったりすればいつでも再び疫病に見まわ れる恐れがある。水道水の安全性は水道施設そのものよ りも水質管理のあり方にかかっていると言える。塩素消 毒を例にあげると, 給配水系統の末端の残留塩素をおろ そかにすれば, 浄水操作によって水質基準が確実に守ら れたとしても安全な水が得にくい。なお, 給配水管のき 裂が避けられない以上, 污水の侵入を防止するために一 
定の水圧を維持しなければならない。一定の水圧を保つ ことはコストがかかるが水質管理の一環として重要であ る。さらに配水管の修理に際しても污染をうけ易いので 工事後の通水時には十分な注意を要する。適切な水質管 理はまた住居の蛇口にまで及ばなければならない。とく に高層住宅においては水は概して屋上の高置水槽を経由 してきており, 水槽の衛生管理や給水栓における水質検 査が必要となる。

水道にはバクテリアの水質基準が設けられており, 水 質検査も定期的に行なわ机てるが，ウイルスについては 何らの基準もない。水道水を介しての一切の感染症を予 防するためには，バクテリアよりも耐性の強いウイルス についての水質基準を早急に確立するよう努力していく べきである。病原体に関する現行の水質基準はバクテリ アについてのものであり,また給配水系統の末端まで消 毒が行き届くように定められた残留塩素の濃度もバクテ リアが主な対象である。したがってウイルスに対しては 必らずしも有効とはいえない。

細菌学的水質基準に合格している各種の用水から往々 にしてウイルスが検出されている。イスラェルで飲料水, プール用水, 表流水, 地下水の各種の水について調査し た結果，155のサンプルのうち45にウイルスが含まれて いた。な損便性の污染指標となる大腸菌が検出されな かった試料水にもウイルスの検出があった。 ${ }^{26)}$ 大腸菌で 代表される細菌学的指標はウイルスをコントロールする うえにおいて信頼性に疑問がある。そのため，各種の用 水についてバクテリアとは別にウイルスに関する基準を 設ける必要がある。一応のクライテリアとしては飲料水 100 ガロンあたり，またりクリエーション用水 10 ガ口 ンあたり 1 PFU以下のウイルス濃度を保つべきであると いう提案もなされているが, ${ }^{27)} こ の$ 方面の研究がもっと 充実されることを望みたい。

水系ウイルスをコントロールするには, ウイルスの水 質基準を設けると同時に, ウイルスの濃縮や試験方法の 確立, さらに指標となるウイルスの選定にも取り組まな ければならない。ポリオウイルスを指標として水系ウイ ルスに対する水の安全性を考える人もいるが，他種のウ イルスにくらべてポリオウイルスは必ずしも強い耐性を 持たず，ポリオウイルスが検出されない試料水からも病 原性をもつ種々のウイルスの検出を見ることがある。ウ イルス污染の程度を包括的に推定する目的で用いられる 指標ウイルスは消毒に強く, 耐性があって広く水域に分 布し, しかも検出し易いものを理想とする。指標ウイル スとしてよく論じられているものにコリファージがある。 大腸菌を宿主とするコリファージは，10 倍ないし 1000 倍もの高い濃度で腸内ウイルスと共に水中に存在し検出 し易いウイルスである。コリファージはまた腸内ウイル
スに比べて消毒に強く, 耐性がある一方, 病原性をもた ないという利点がある。しかし，コリファージも種類が 多く, それらの検出に用いる宿主細菌に, 多くの大腸菌 のうち,どれを用いるかに問題がある。また塩素に対す る耐性が大腸菌と大差ないという報告も多い。

現在の水質基準には, バクテリアに関する基準が組み 込まれており, それが環境衛生の改善や上下水道の普及 とあいまって, コレラやチフスといったような伝統的水 系伝染病の防止に役立ってきたことは見逃せない事実で ある。ところでウイルスに関する水質基準は現在なお議 論の的であり，それが確立できれば毎年のように流行し てきた流行性肝炎のようなウイルス性疫病をもコントロ ールすることができたであろう。

(原稿受理：昭和 56 年 6 月 10 日)

\section{一 引用 文 献 -}

1) Rhodes, A.J。and C.E. VanRooyen (1962) Textbook of Virology, 4 th ed., Williams \& Wilkins, Baltimore, Maryland, U.S.A.

2) Grinstein, S., J.L. Melnick and C. Wallis (1970)

Virus isolation from sewage and from a stream receiving effluents of sewage, Bulletin of the World Heal th Organization, 42 (2), 291.

3) Peterson, M. L. (1974)

Soiled disposable diapers: a potential source of viruses, American Journal of Public Health, $64(9), 912$.

4) Hoffman, A.M., T.C. Crusberg and B.J.Savilonis (1979)

Viral hepatitis and hydraulic parameters: an alternative hypothesis, Archieves of Enviromental Heal th, $34(2), 87$.

5) Committee Report (1979)

Prevention of groundwater backflow into distribution systems, Journal American Water Works Association, 71 (2), 76 .

6) Bagdasar'yan, G.A. (1964)

Sanitary virological examination of soil and vegetables in irrigation fields, Hygiene and Sanitation (translation of the Russian journal, Gigiena i Sanitariya), 29 (11), 36 .

7) Grigor' eva, L.V., A.S. Gorodetskii, T. G. Omel'yanets and L.A. Bogdanenko (1965) Survival of bacteria and viruses on vegetable crops irrigated with infected water, Hygiene 
and Sanitation (translation of the Russian journal, Gigiena i Sanitariya), 30 (10-12), 357 .

8) Goyal, S.M., C.P. Gerba and J.C. Melnick (1979)

Human enteroviruses in oysters and their overlying water, Applied and Environmental Microbiology, 37 (3), 572 .

9) Ringertz, O. (1971)

Some aspects of the epidemiology of hepatitis in Sweden, Post-Graduate Medical Journa $1,47,465$.

10 ) Fugate, K.J., D.O.Cliver and M.T.Hatch (1975)

Enteroviruses and potential bacterial indicators in Gulf Coast oysters, Journal of Milk and Food Technology, 38 (2), 100 .

11) Chanlett, E. T. (1973)

Environmental Protection, P. 52, McGrawHill Book Company, New York, U. S. A.

12) Teltsch, B. and Katzenelson, E. (1978) Airborne enteric bacteria and viruses from spray irrigation with wastewater, Applied and Environmental Microbiology, 35 (2), 290 .

13) Katzenelson, E. and H. I. Shuval (1977) Discussion on "Disease Risks of Occupational Exposure to Sewage," Journal of the Environmental Engineering Divisin, Proceedings of the American Society of Civil Engineers, 103 ( E E 4 ), 746 .

14) Viswanathan, R. (1957)

Infectious hepatitis in Dehli (1955-1956): a critical study, Indian Journal of Medical Research, 45 (Supplement $N_{0.1}$ ).

15) Sobsey, M.D. (1975)

Enteric viruses and drinking-water supplies, Journal of American Water Works Association, $67(8), 414$.

16) McDermott, J.H. (1975)

Virus problems in water supplies, Water \& Sewage Works, $122(5), 71$.

17) Neefe, J.R. and J.Stokes (1945)
An epidemic of infectious hepatitis apparently due to a water borne agent, Journal of the American Medical Association, 128 (15), 1063 .

18) Bancroft, P.M., W。E. Engelhardt and C.A. Evans (1957)

Poliomyelitis in Huskerville (Lincoln) Nebraska, Journal of the American Medical Association, $164(8), 836$.

19 ）鈴木每, 横尾和伸, 坂川勉, 早瀬隆司, 八木美雄 (1981)

国際水道と衛生の 10 力年計画, 水道協会誌, 561 , 29 .

20) 中村正 (1979)

公衆衛生学 講談社 サンエンティフイク

21 ) 滝口洋 (1979)

ウイルスとその水污染, 水処理技術 $20(8), 61$.

22) Mosely, J.W。(1965)

Transmission of viral diseases by drinking water. Proceedings of the Conference of Transmission of Viruses by the Water Route, Interscince Publishers, New York, U.S.A.

23 ) Wiley, J.S., T.D.Y.Chin, C.R. Gravalle and S. Robinson (1962)

Enterovirus in sewage during a poliomyelitis epidemic, Journal Water Pollution Control Federation, $34(2), 168$.

24) Clarke, N.A. and S.L. Chang (1959) Enteric viruses in water, Journal American Water Works Association, 51 (10), 1299.

25 ) 览玉威（1973） 水と腸内ウイルス, 水, $15(8), 31$.

26) Marzouk, Y., S.M. Goyal and C.P. Gerba (1980)

Relationship of viruses and indicator bacteria in water and wastewater of Isreal, Water. Research, 14 (11), 1585 .

27) Melnick, J.L. (1971)

Detection of virus spread by the water route, Proceedings, Thirteenth Water Quality Conference, University of Illinois, Urbana, Illinois, U.S.A. 